\title{
Forløpsbasert finansiering: Gammel vin i nye skinnsekker?
}

KOMMENTAR

\section{TORGEIR BRUUN WYLLER}

E-post: t.b.wyller@medisin.uio.no Torgeir Bruun Wyller er spesialist i indremedisin og i geriatri, professor og overlege samt styreleder i Helsetjenesteaksjonen.

Forfatteren har ikke oppgitt noen interessekonflikter.

Christer Mjåset og medarbeidere ga i Tidsskriftet nylig en god og kritisk redegjørelse for prinsippene bak forløpsbasert finansiering (1). Likevel sitter man som leser igjen med betydelig tvil om hvorvidt forløpsbaset finansiering vil representere noe fremskritt sammenliknet med dagens system for innsatsstyrt finansiering (ISF) basert på diagnoserelaterte grupper (DRG).

Det mest fundamentale problemet med ISF-systemet er at det er utviklet for en kommersiell og profittstyrt amerikansk helsetjeneste. Vår helsetjeneste har, i motsetning til den amerikanske, i stor grad vært basert på at helseinstitusjoner opprettes for å tjene pasientene, ikke eierne. Videre forutsetter vårt system at helsepersonell i stor grad styres av faglige og fagetiske normer, ikke av profittønske (2). Disse prinsippene har medført at skandinavisk helsetjeneste - igjen i motsetning til den amerikanske - har gitt mye helse for pengene.

Ideologien bak ISF-systemet har vist seg å true den skandinaviske helsetjenestens kjerneverdier og effektivitet, av flere grunner:

- Aktørene betrakter hverandre som konkurrenter i et marked, og gjør strategiske tilpasninger styrt av en slik idé. Dette hemmer i stedet for å fremme samarbeid om god pasientbehandling, og gjør at økonomiske resonnementer får forrang foran en vurdering av hva som tjener pasientene.

- Det skjer et tap av tillit med derav økt kontrollbehov (3).

- Det generes store mengder uproduktivt arbeid, som f.eks. å gjøre legene til ekvilibrister i strategisk diagnosesetting eller å ansette kodekonsulenter hvis arbeid er uten betydning for pasientbehandlingen.

- Sykehusdrift etter industriell modell belønnes. Pasienter som har én veldefinert «feil» som kan «repareres» på et samlebånd, er perfekte i et slikt system. Men pasienter flest har sammensatte og komplekse helseproblemer som krever innsikt, forståelse, kommunikasjon, helsefaglig tankearbeid og omsorg. De obstruerer samlebåndet og blir uønskede. 
Som Haldor Byrkjeflot, en av Mjåsets medforfattere, tidligere har påpekt, ble systemet for DRG-basert finansiering i sin tid eksportert fra USA til Skandinavia med rekordfart, takket være en overivrig lobby og uten vesentlig drøfting av hvorvidt systemet var egnet for en offentlig helsetjeneste (4). Det ble hevdet at det var «nødvendig» å forlate systemet med rammefinansiering for å få kontroll med helseutgiftene. Er det blitt evaluert hvorvidt innføringen av ISF faktisk førte til økt effektivitet, eller har ISF tvert imot ført til økte utgifter der en større andel utgjøres av administrasjons- og transaksjonskostnader?

Kan vi forvente at forløpsbasert finansiering vil avhjelpe de problemene som ISF har påført oss? Det er tvilsomt. Som Mjåset og medarbeidere viser, er de grunnleggende idéene de samme. Den viktigste forskjellen er at grunnlaget for de kvasikapitalistiske transaksjonene skiftes fra en sykehusbasert diagnose til et mer omfattende men fortsatt standardisert forløp. Det er symboltungt når Mjåset og medarbeidere konsekvent bruker termen «leverandør» om dem som behandler pasienter. Det er en kraftfull påminnelse om hvordan systemer utviklet for en profittstyrt helsetjeneste trekker med seg en tenkemåte og en terminologi som fortrenger det som har vært den offentlige helsetjenestens adelsmerke, nemlig det moralske imperativet om å hjelpe pasienter uten pekuniære sideblikk. Ikke slik å forstå at helsetjenesten kan eller bør operere uten økonomiske rammer. Det nye med ISFsystemet var at det økonomiske språket på en helt annen måte enn før ble dominerende i konsultasjonsrommet og ved pasientsengen, og der langt på vei fikk fortrenge de helsefaglige overveielsene. Det er grunn til å frykte at systemet med forløpsbasert finansiering vil føre denne utviklingen ytterligere et skritt videre fordi systemet omfatter en enda større del av den sykes møte med helsetjenesten. Det er ikke vanskelig å se hvordan strategiske og økonomisk motiverte tilpasninger til et slikt system kan gi uheldige konsekvenser for pasientene. Hvis f.eks. reinnleggelser brukes som kvalitetsindikator, er det lett å få høyere registrert «kvalitet» ved å la være å reinnlegge pasienter som ville hatt nytte av det. Slikt ser vi mye av allerede i dagens system.

Mens Mjåset og medarbeidere skriver at «mangelen på konkurranse ... kan være en utfordring», vil jeg tvert imot fremheve fraværet av profittorientering og økonomisk motivert konkurranse som et av de viktigste fortrinnene ved det som til nå har vært regnet som den skandinaviske velferdsmodellen. Det kan ikke være slik at vi skal gjøre den norske, offentlige helsetjenesten mer kvasikapitalistisk for å passe til et system for forløpsbasert finansiering. Tvert imot må vi arbeide for et finansieringssystem som er tilpasset en offentlig finansiert helsetjeneste med de kvaliteter en slik organisering på sitt beste kan gi.

\section{LITTERATUR:}

1. Mjåset C, Byrkjeflot H, Hanssen FASR et al. En introduksjon til forløpsbasert finansiering. Tidsskr Nor Legeforen 2020; 140. doi: 10.4045/tidsskr.20.0367. [PubMed][CrossRef]

2. Wyller VB, Gisvold SE, Hagen E et al. Ta faget tilbake! Tidsskr Nor Legeforen 2013; 133: 655-9. [PubMed][CrossRef]

3. Lægreid P, Neby S. Gaming, accountability and trust: DRGs and activity-based funding in Norway. Financ Account Manag 2016; 32: 57-79. [CrossRef]

4. Byrkjeflot $\mathrm{H}$, Torjesen DO. Managerial innovation in health care. The introduction, translation and use of the American DRG System in the hospital sectors in Norway and Denmark. I: Knudsen H, Falkenberg J, Grønhaug K et al. Mysterion, strategike og kainotomia. Oslo: Novus, 2010: 130-48.

Publisert: 9. november 2020. Tidsskr Nor Legeforen. DOI: 10.4045/tidsskr.20.o835

(C) Tidsskrift for Den norske legeforening 2020. Lastet ned fra tidsskriftet.no 